\title{
PENGEMBANGAN ALAT PERMAINAN EDUKATIF SAPI PERAH DALAM PEMBELAJARAN ANAK USIA DINI
}

\author{
Husimah $^{1}$ Retoliah $^{2}$ Hikmatur Rahmah $^{3}$ \\ ${ }^{1}$ Mahasiswa Program Studi PIAUD FTIK Institut Universitas Islam Negeri Datokarama Palu \\ ${ }^{2}$ Dosen Fakultas Tarbiyah dan Ilmu Keguruan Universitas Islam Negeri Datokarama Palu \\ ${ }^{3}$ Dosen Fakultas Tarbiyah dan Ilmu Keguruan Universitas Islam Negeri Datokarama Palu
}

\begin{abstract}
ABSTRAK
Penelitian ini membahas tentang pengembangan alat permainan edukatif sapi perah dalam pembelajaran anak usia dini. Adapun rumusan masalah sebagai berikut: Pertama, bagaimana kelayakan alat permaianan edukatif sapi perah dalam pembelajaran anak usia dini. Kedua, bagaimana pengaruh alat permainan edukatif sapi perah dalam pembelajaran anak usia dini. Adapun metode penelitian dalam skripsi ini adalah menggunakan metode Research And Development (R\&D) merupakan metode penelitian yang digunakan untuk menghasilkan produk tertentu, dan menguji kelayakan produk tersebut, Penelitian ini menggunakan teknik potensi dan masalah, pengumpulan data, desain produk, validasi desain, perbaikan desain, uji coba produk, dan revisi produk. Berdasarkan hasil uji validasi oleh tim validator mendapatkan persentase dengan kategori valid oleh validator I dengan memberikan nilai sebesar 87, dan penilaian validator II memberikan nilai 87 dengan kategori valid, dan validator III. Kategori valid dengan memberikan nilai 86, dan validator IV kategori valid dengan memberikan nilai 80. kemudian penilaian coba terbatas di RA Ummahat DDI Ujuna oleh Ibu Ratnawati S.Pd memberikan nilai 4 dengan kategori sangat layak, RA DWP 1 Kanwil Depertemen Agama oleh Ibu Samsia S.Pd.I memberikan nilai 4 dengan kategori sangat layak, RA DWP 2 Kanwil Depertemen Agama oleh Ibu Ria Ika Rahayuningtyas memberikan nilai 3,7 dengan kategori sangat layak. penilaian uji coba lapangan mendapatkan respon baik oleh peserta didik. Berdasarkan hasil penilaian pengembangan alat permainan edukatif sapi perah dalam pembelajaran anak usia dini dikatakan layak karena perolehan persentase skor tiap aspek valid dan sangat baik sehingga media alat permainan edukatif sapi perah sangat layak digunakan sebagai media pembelajaran anak usia dini.Implikasi bagi semua komponen dapat mengembangkan media pembelajaran beru alat permainan edukatif sapi perah sehingga dapat meningkatkan evektivitas pembelajaran, yang edukatif, inovatif dan kreatif dalam pembelajaran anak usia dini sehingga perkembangan anak dapat berkembang secara optimal.
\end{abstract}

Kata Kunci : Alat Permainan Edukatif, Anak Usia Dini

\section{PENDAHULUAN}

Pendidikan merupakan suatu upaya pembinaan dalam meningkatkan mutu sumber daya manusia (SDM) di Indonesia. Upaya pembinaan ini di mulai pada pendidikan anak usia dini baik itu secara formal maupun non formal yang dapat 
diselenggarakan dalam keluarga, masyarakat, pemerintah melalui bimbingan, pengajaran dan pelatihan yang di lakukan sepanjang hidup dengan tujuan untuk menciptakan generasi bangsa yang berkualitas. Pendidikan anak usia dini (PAUD) merupakan suatu cara dalam upaya mengembangkan potensi yang dimiliki oleh setiap anak. Anak usia dini dipandang mempunyai krakteristik yang berbeda berdasarkan usia hingga pendidikanya perlu di khususkan. Pendidikan anak usia dini pada dasarya adalah upaya memfasilitaskan perkembangan yang sedang terjadi pada diri anak.

Pendidikan anak usia dini (PAUD) merupakan suatu cara dalam upaya mengembangkan potensi yang dimiliki oleh setiap anak. Anak usia dini dipandang mempunyai krakteristik yang berbeda berdasarkan usia hingga pendidikanya perlu di khususkan. Pendidikan anak usia dini pada dasarya adalah upaya memfasilitaskan perkembangan yang sedang terjadi pada diri anak. Perkembangan pada anak usia dini yakni peningkatan kemampuan dan kesadaran anak dalam mengenal dirinya serta berintraksi dengan lingkungan sekitarnya seiring dengan pertumbuhan fisik yang dialami. ${ }^{1}$

Hal yang telah ditegasakan dalam Undang-undang No 20 Tahun 2003 tentang Sistem Pendidikan Nasional Pasal 1 ayat 14 menyatakan bahwa:

Pendidikan Anak Usia Dini (PAUD) adalah Suatu upaya pembinaan yang di tunjukkan kepada anak sejak lahir sampai dengan usia enam tahun yang dilakukan melalui pemberian rangsangan pendidikan untuk membantu pertumbuhan dan perkembanagan jasmani dan rohani agar anak memiliki kesiapan dalam memasuki pendidikan lebih lanjut baik dalam jalur pendidikan formal maupun non formal. ${ }^{2}$

Menurut Mansyur pendidikan anak usia dini merupakan proses pembinaan pertumbuhan dan perkembangan anak usia sejak lahir hingga usia enam tahun secara menyeluruh, yang mencakup seluruh aspek fisik dan non fisik, dengan memberikan ransangan bagi perkembangan fisik motorik, akal pikir, sosial emosional, dan bahasa yang tepat agar anak tumbuh dan berkembang secara optimal. ${ }^{3}$

Pada masa usia ini anak usia dini identik dengan keceriaan, kesenangan, dan kegembiraan. Pada masa ini juga kita sering mendengar dengan kata Golden Age masa keemasan dimana $80 \%$ otak anak sudah bekerja dan ditandai pada perubahan

${ }^{1}$ Yuliani Nurani Sujiono, Konsep Dasar Pendidikan Anak Usia Dini (Jakarta: PT Indeks, 2005), 7.

2 Peraturan Menteri Pendidikan Nasional Republik Indonesia No 137 Tahun 2014 Tentang Standar Pendidikan Anak Usia Dini (Jakarta: Madya Duta Jakarta)

${ }^{3}$ Mansyur, Pendidikan Anak Usia Dini Dalam Islam (Yogyakarta:Pustaka Pelajar, 2011), 8889. 
dalam setiap perkembangan secara cepat baik pada fisik motorik, bahasa, kognitif, sosial emosional, moral, agama dan seni.

Proses membangun pendidikan anak usia dini tidaklah sama seperti membangun pendidikan anak-anak pada usia sekolah dasar. Pendidikan anak usia dini di kenal dengan pendidikan pra sekolah yaitu pendidikan melalui pemberian kesempatan bagi anak untuk dapat menikmati dunianya yaitu dunia main. Main menjadi sarana untuk anak belajar sehingga dapat dikatakan bahwa belajar anak usia dini adalah bermain. ${ }^{4}$ Alat permainan edukatif memegang peranan penting dalam menentukan keberhasilan pendidikan juga dalam menyiapkan peserta didik sebagai generasi bangsa yang berkualitas untuk memasuki era globalisasi yang penuh dengan berbagai tantangan dan permasalahan yang sangat kompleks.

RA Ummahat DDI Ujuna palu, RA DWP 1 Kanwil Depertemen Agama dan RA DWP 2 Kanwil Depertemen Agama, merupakan sekolah yang berusaha keras untuk memaksimalkan potensi yang dimiliki anak agar mencapai hasil yang maksimal, di tiga sekolah tersebut memiliki berbagai macam media alat permainan adukatif yang tentunya berbeda dari segi kualitas, di RA DWP 2 Kanwil Depertemen Agama berdasarkan observasi awal terlihat sekolah ini kekurangan alat permainan edukatif juga kekurang efektifan dalam penggunaan media pembelajaran, di RA Ummahat DDI Ujuna terdapat berbagai macam alat permainan edukatif namun tentunya sekolah ini masih sangat memerlukan beberapa media alat permainan edukatif untuk mendukung proses pembelajaran, sedangkan di RA DWP 1 Kanwil Depertemen Agama terdapat berbagai macam alat permainan edukatif yang dapat mendukung pembelajaran anak usia dini, berdasarkan observasi awal dari ketiga sekolah tersebut memiliki jumlah kualitas alat permainan edukatif yang berbedabeda, dalam pembelajaran dengan tema binatang khusus ke hewan sapi ketiga sekolah tersebut tidak memiliki media langsung untuk mengajarkan kepada anak usia dini maka penulis tertarik untuk membuat alat permainan edukatif sapi perah dimana alat ini dapat mendukung daya tangkap mereka dalam memahami pembelajaran.

\section{A. Alat Permainan Edukatif Sapi Perah}

Alat Permainan Edukatif adalah alat yang digunakan oleh anak untuk bermain sambil belajar artinya alat dan bermain itu sendiri merupakan sarana belajar yang menyenangkan dari sudut pandang materinya alat permaianan harus mampu mengembangkan daya pikir (kognisi), aspek bahasa, motorik dan keterampilan.

\footnotetext{
${ }^{4}$ Mukhtar latif, dkk, Orientasi Baru Pendidikan Anak Usia Dini : Teori dan Aplikasinya (cet.3; Jakarta : Prenadamedia group. 2016), 5-7.
} 


\section{B. Pembelajaran Anak Usia Dini}

Pembelajaran adalah suatu rangkaian kondisi, peristiwa, dan kejadian dalam mengembangkan pengetahuan, keterampilan seseorang individu saat berinteraksi dengan lingkungannya. Untuk mencapai tujuan pembelajaran yang efektif seorang guru harus mempunyai Kompetensi Pedagogik yang merupakan suatu kemampuan seseorang dalam mengelola pembelajaran anak yang meliputi pemahaman terhadap peserta didik, perancangan dan pelaksanaan pembelajaran, evaluasi dan hasil belajar, dan pengembangan anak untuk mengaktualisasikan berbagai potensi yang dimilikinya. ${ }^{5}$ Pembelajaran adalah pengembangan pengetahuan, keterampilan, atau sikap baru ada saat seseorang individu berinteraksi dengan lingkungan. Pembelajaran yang memiliki berbagai macam metode penyampaian pada siswa. Pembelajaran sebagai suatu rangkaian (kondisi, peristiwa, dan kejadian) yang secara sengaja dirancang untuk mempengaruhi pembelajaran, sehingga proses belajarnya dapat berlangsung mudah.

\section{METODE PENELITIAN}

Penelitian ini menggunakan metode pengembangan, atau di sebut juga dengan Research and Development adalah metode penelitian yang digunakan untuk menghasilkan produk.Metode Research and Development (R\&D) merupakan mertode penelitian yang digunakan untuk menghasilkan produk tertentu, dan menguji kefektifan produk tersebut penelitian di lakukan secara bertahap/longitudinal agar hasil dari produk tersebut bisa beranfaat bagi masyarakat luas. ${ }^{6}$ Model pengembangan dalam penelitian ini menggunakan model prosedural yang bersifat deskriptif yang dikembangkan oleh Borg an Gall. ${ }^{7}$ Adapun prosedur atau langkah-langkah yang dikembangkan dari model Borg and Gall yang telah dimodifikasi sugiyono yang terdiri dari sepuluh langkah sebagai berikut: 1) potensi dan masalah 2) pengumpulan data 3) desain produk 4) validasi desain 5) perbaikan desain 6) uji coba produk 7) revisi produk 8) uji coba pemakaian 9) revisi produk 10) produksi masal.

\footnotetext{
5 Romlah, Untung Nopriansyah, Sigit Purnama, Korelasi Kepemimpinan Kepala Taman Kanak-Kanak Terhadap Kinerja Kompetensi Pedagogik Dan Kompetensi Profesional Guru , Al Athfaal:Jurnal ilmiah Pendidikan Anak Uisa Dini . Vol. 2 No. 1(2019). 5

${ }^{6}$ Sugiyono, Metode Penelitian Pendidikan Pendekatan Kuantitatif, Kualitatif Dan RnD (Bandung : Alfabeta, 2015), 407.

${ }^{7}$ Punaji Setyosari, Metode Penelitian Pendidikan Dan Pengembangan (Jakarta: Prenadamedia Group, 2013), 292.
} 
Berdasarkan tahapan penelitian, peneliti melakukan penyederhanaan dan pembatasan langkah-langkah penelitian pengembangan dari sepuluh langkah menjadi tujuh langkah sampai revisi produk dikarenakan sesuai dengan kebutuhan pengembangan. ${ }^{8}$ Penyederhanaan dilakukan karena beberapa factor, adapun factor tersebut adalah Keterbatasan Waktu dan Keterbatasan Dana.

Berikut prosedur atau langkah-langkah yang digunakan pada penelitian ini

1. Potensi dan Masalah

2. Pengumpulan Data

3. Desain Produk

4. Validasi Desain

5. Perbaikan Desain

6. Uji Coba Produk

7. Revisi

8. Produk

Instrument yang digunakan adalah angket untuk mendapatkan penilaian dari ahli tentang kelayakan alat permainan edukatif sapi perah ditinjau dari beberapa aspek yaitu aspek kelayakan alat permaianan, aspek desain dan aspek kemudahan penggunaan. Penelitian pengembangan ini perlu digunakan metode yang tepat, selain itu perlu memiliki teknik dan alat pengumpulan data yang relavan. Penggunaan teknik dan alat pengumpul data yang tepat memungkinkan diperolehnya data yang objektif $^{9}$ tehnik pengumpulan data dalam penelitian ini terdiri dari angket, dokumentasi dan wawancara.

\section{HASIL DAN PEMBAHASAN}

\section{A. Desain Produk Awal}

Pengembangan produk yang dihasilkan berupa alat permainan edukatif sapi perah dari bahan dasar koran dan kawat, dengan tema binatang sebagai media pembelajaran anak usia dini, dalam pengembangan alat permainan edukatif sapi perah di uji cobakan pada tiga sekolah yang berbeda dari segi kualitas dan kuantitas alat permainan edukatif yang berada di sekolah tersebut, yaitu sekolah RA Ummahat DDI Ujuna, RA DWP 1 Kanwil Depertemen Agama, dan RA DWP 2 Kanwil

\footnotetext{
${ }^{8}$ Yasa, "Pengembangan Bahan Ajar Online Mata Kuliah Microteaching Dengan Model Borg \& Gall Pada Program S1 Pendidikan Bahasa Inggris STKIP Agama Hindu Singaraja." Teknologi Pendidikan (2012), 8.

${ }^{9}$ Margono, metodelogi penelitian pendidikan (Jakarta: Rineka cipta, 2010), 158.
} 
Depertemen Agama. Pengembangan produk ini berawal dari potensi dan masalah yang di dapatkan di lapangan dengan melakukan observasi awal di tiga sekolah tersebut bahwa di RA Ummahat DDI Ujuna, RA DWP 1 Kanwil Depertemen Agama, dan RA DWP 2 Kanwil Depertemen Agama ini penggunaan alat permainan edukatif sapi perah belum pernah di gunakan sebagai media pembelajaran, selama ini peserta didik ketika mempelajari tema tersebut hanya melalui media gambar atau video, kebutuhan akan susu sapi segar yang berasal dari sapi perah semakin tinggi sedangkan kebutuhan biaya, pengetahuan dan lingkungan untuk mengembangkan sebuah perternakan sapi perah tidaklah gampang dan murah, sehingga sulit bagi pelajar dan masyarakat pada umumnya dapat mempelajari teknis peroses pemerahan sapi secara langsung, dari potensi dan masalah yang ada peneliti ingin mengembangkan alat permainan edukatif sapi perah sebagai media pembelajaran anak usia dini yang dapat membantu aspek perkembangan anak usia dini.

Berdasarkan potensi dan masalah serta pengumpulan data yang telah dilakukan maka peneliti mendesain produk alat permainan edukatif sapi perah untuk mengembangkan aspek perkembangan anak usia dini. Alat permainan edukatif sapi perah ini terbuat dari bahan koran, kawat prabola, sagu/lem, handsoon, botol madu TJ dan cet, pembuatan alat permainan edukatif sapi perah ini dirancang dan dijahit langsung oleh peneliti.

\section{A. Hasil Pengujian Tahap 1}

Pembuatan produk awal alat permainan edukatif sapi perah sebagai media pembelajaran dalam perkembangan anak usia dini selesai dirancang selanjutnya pengujian produk ini akan divalidasi oleh 4 tim ahli validator, adapun data dari tim validator dapat dilihat pada tebel berikut :

Data Tim Ahli Validator

\begin{tabular}{|l|l|l|l|}
\hline No & \multicolumn{1}{|c|}{ Nama } & \multicolumn{1}{|c|}{ Jabatan } & \multicolumn{1}{c|}{$\begin{array}{c}\text { Tim } \\
\text { Validator }\end{array}$} \\
\hline 1 & Hamka, S. Ag., M.Ag. & $\begin{array}{l}\text { Kepala Pusat Pengembangan } \\
\text { Standar Mutu Akademik } \\
\text { IAIN Palu }\end{array}$ & Validator I \\
\hline 2 & Dra. Retoliah, M.Pd.I. & Dosen PAUD IAIN Palu & Validator II \\
\hline 3 & Hikmatur Rahma Lc., M. Ed. & Dosen PIAUD IAIN Palu & $\begin{array}{l}\text { Validator } \\
\text { III }\end{array}$ \\
\hline 4 & Nurni kinabi S. Pd. I & Ketua IGRA Sulteng & $\begin{array}{l}\text { Validator } \\
\text { IV }\end{array}$ \\
\hline
\end{tabular}


Hasil validasi oleh tim validator pada produk alat permainan edukatif sapi perah di isi tim validator melalui google from dan penulis sajikan dalam bentuk tabel berikut:

1. Hasil penilaian Uji validator I

\section{Hasil Penilaian Uji Validator I}

\begin{tabular}{|c|l|c|}
\hline No & \multicolumn{1}{|c|}{ Materi } & Skor \\
\hline 1 & Kesesuaian media dengan tujuan yang ingin dicapai & 8 \\
\hline 2 & Kesesuaian krakteristik media dengan proses pembelajaran & 9 \\
\hline 3 & Media dapat mendukung isi dan bahan pembelajaran & 9 \\
\hline 4 & Media mudah diperoleh & 7 \\
\hline 5 & Media mudah diakses (tidak sulit digunakan) & 9 \\
\hline 6 & Efesiensi waktu dalam penggunaan media dalam pembelajaran & 9 \\
\hline 7 & Efesiensi waktu dalam penggunaan media dalam pembelajaran & 9 \\
\hline 8 & Kesesuaian media dengan situasi dan kondisi lingkungan & 8 \\
\hline 9 & Kesesuaian media dengan tingkat pengetahuan dan skil para guru & 9 \\
\hline 10 & Tingkat efektivitas media dalam pembelajaran & 9 \\
\hline \multicolumn{2}{r}{ Total } & $\mathbf{8 7}$ \\
\hline \multicolumn{2}{|c|}{ Keterangan } & Valid \\
\hline
\end{tabular}

Berdasarkan uji validasi oleh tim validator I diatas skor tiap aspek penilaian yang terendah pada nomor 4 dengan memberikan nilai 7, nomor 1 dan 8 memberikan nilai 8 , seluruh jumlah nilai skor tiap aspek penilaian di kali $100 \%$, dibagi skor maksimun, sehingga memperoleh nilai praktikalitas dengan kategori valid.

2. Hasil Penilaian Uji Validator II

Hasil Penilaian Uji Validator II

\begin{tabular}{|c|l|c|}
\hline No & \multicolumn{1}{|c|}{ Materi } & Skor \\
\hline 1 & Kesesuaian media dengan tujuan yang ingin dicapai & 9 \\
\hline 2 & Kesesuaian krakteristik media dengan proses pembelajaran & 9 \\
\hline 3 & Media dapat mendukung isi dan bahan pembelajaran & 9 \\
\hline 4 & Media mudah diperoleh & 9 \\
\hline 5 & Media mudah diakses (tidak sulit digunakan) & 9 \\
\hline 6 & $\begin{array}{l}\text { Efesiensi waktu dalam penggunaan media dalam } \\
\text { pembelajaran }\end{array}$ & 8 \\
\hline 7 & $\begin{array}{l}\text { Efesiensi waktu dalam penggunaan media dalam } \\
\text { pembelajaran }\end{array}$ & 8 \\
\hline 8 & $\begin{array}{l}\text { Kesesuaian media dengan situasi dan kondisi lingkungan } \\
\text { Kesesuaian media dengan tingkat pengetahuan dan skil para } \\
\text { guru }\end{array}$ & 8 \\
\hline 10 & Tingkat efektivitas media dalam pembelajaran & 9 \\
\hline \multicolumn{2}{|c|}{ Total } & $\mathbf{8 7}$ \\
\hline & \multicolumn{1}{|c|}{ Keterangan } \\
\hline
\end{tabular}


Berdasarkan uji validasi oleh tim validator II di atas skor tiap aspek penilaian yang terendah pada nomor 6,7,8 dengan memberikan nilai 8 , seluruh jumlah nilai skor tiap aspek penilaian di kali $100 \%$, dibagi skor maksimun, sehingga memperoleh nilai praktikalitas dengan kategori valid.

3. Hasil Penilaian Uji Validator III

Uji Validator III

\begin{tabular}{|c|l|c|}
\hline No & \multicolumn{1}{|c|}{ Materi } & Skor \\
\hline 1 & Kesesuaian media dengan tujuan yang ingin dicapai & 8 \\
\hline 2 & Kesesuaian krakteristik media dengan proses pembelajaran & 8 \\
\hline 3 & Media dapat mendukung isi dan bahan pembelajaran & 9 \\
\hline 4 & Media mudah diperoleh & 7 \\
\hline 5 & Media mudah diakses (tidak sulit digunakan) & 9 \\
\hline 6 & Efesiensi waktu dalam penggunaan media dalam pembelajaran & 9 \\
\hline 7 & Efesiensi waktu dalam penggunaan media dalam pembelajaran & 9 \\
\hline 8 & Kesesuaian media dengan situasi dan kondisi lingkungan & 9 \\
\hline 9 & Kesesuaian media dengan tingkat pengetahuan dan skil para guru & 9 \\
\hline 10 & Tingkat efektivitas media dalam pembelajaran & 9 \\
\hline \multicolumn{2}{|c|}{ Total } & $\mathbf{8 6}$ \\
\hline & Keterangan & Valid \\
\hline
\end{tabular}

Berdasarkan uji validasi oleh tim validator III diatas skor tiap aspek penilaian yang terendah pada nomor 4 dengan memberikan nilai 7, nomor 1 dan 2 memberikan nilai 8 , seluruh jumlah nilai skor tiap aspek penilaian di kali $100 \%$, dibagi skor maksimun, sehingga memperoleh nilai praktikalitas dengan kategori valid.

4. Hasil Penilaian Uji Validator IV

Hasil Penilaian Uji Validator IV

\begin{tabular}{|c|l|c|}
\hline No & \multicolumn{1}{|c|}{ Materi } & Skor \\
\hline 1 & Kesesuaian media dengan tujuan yang ingin dicapai & 7 \\
\hline 2 & Kesesuaian krakteristik media dengan proses pembelajaran & 8 \\
\hline 3 & Media dapat mendukung isi dan bahan pembelajaran & 7 \\
\hline 4 & Media mudah diperoleh & 8 \\
\hline 5 & Media mudah diakses (tidak sulit digunakan) & 9 \\
\hline 6 & Efesiensi waktu dalam penggunaan media dalam pembelajaran & 8 \\
\hline 7 & Efesiensi waktu dalam penggunaan media dalam pembelajaran & 8 \\
\hline 8 & Kesesuaian media dengan situasi dan kondisi lingkungan & 8 \\
\hline 9 & Kesesuaian media dengan tingkat pengetahuan dan skil para guru & 9 \\
\hline 10 & Tingkat efektivitas media dalam pembelajaran & 8 \\
\hline \multicolumn{2}{r}{ Total } & $\mathbf{8 0}$ \\
\hline & Keterangan & Valid \\
\hline
\end{tabular}

Berdasarkan uji validasi oleh tim validator IV di atas skor tiap aspek penilaian yang terendah pada nomor 1 dan3 dengan memberikan nilai 7 , nomor 2,4,6,7,8 dan 
10 memberikan nilai 8, seluruh jumlah nilai skor tiap aspek penilaian di kali $100 \%$, dibagi skor maksimun, sehingga memperoleh nilai praktikalitas dengan kategori valid.

\section{B. Revisi Produk/ Perbaikan Desain}

Setelah dilakukan penilaian produk yang dilakukan oleh tim ahli validator maka di dapat saran dari para validator, kemudian saran yang diberikan di jadikan masukan untuk merevisi desain produk, adapun hasil revisi yang dijelaskan sebagai berikut:

1. Konstruk media pada aspek estetika/keindahan masih perlu dipoles agar sesuai dengan aslinya

2. Proporsi badan dan tingginya perlu di sesuaikan

3. Wajah sapi masih datar, dan masih menyerupai hewan anjing maka perlu di tambah agar kelihatan lebih berisi

4. Pemilihan warnanya sebaiknya warna hitam putih

\section{Hasil pengujian Tahap ke II}

\section{Validasi Penilaian Guru}

Tahapan uji coba yang dilakukan penulis adalah pengujian terbatas dalam uji coba penelitian ini melibatkan guru di RA Ummahat DDI Ujuna Palu, RA DWP 1 Kanwil Depertemen Agama, dan RA DWP 2 Kanwil Depertemen Agama Untuk menilai produk yang dikembangkan dari berbagai aspek. Pertimbangan peneliti untuk melibatkan guru dalam menilai produk dikarenakan guru merupakan calon pengguna dan pelaksana pembelajaran. Hasil penilain guru terhadap produk yang di kembangkan dapat dilihat pada table berikut:

1. RA Ummahat DDI Ujuna ( Ibu Ratnawati S. Pd)

Hasil penilaian pendidik RA Ummahat DDI Ujuna

\begin{tabular}{|c|l|c|}
\hline No & \multicolumn{1}{|c|}{ Butir pertanyaan } & Skor \\
\hline 1 & $\begin{array}{l}\text { kesesuian media permainan sapi perah dengan tingkat perkembangan } \\
\text { anak usia dini }\end{array}$ & 4 \\
\hline 2 & $\begin{array}{l}\text { Kesesuaian media permainan sapi perah dengan tujuan pembelajaran } \\
\text { kecerdasan jamak anak usia dini }\end{array}$ & 4 \\
\hline 3 & Kesesuaian media dengan kebutuhan mengajar & 4 \\
\hline 4 & Kejelasan petunjuk permainan Sapi perah & 4 \\
\hline 5 & Bahan permaianan sapi perah tidak bahaya dan aman bagi anak-anak & 4 \\
\hline
\end{tabular}




\begin{tabular}{|c|l|c|}
\hline 6 & $\begin{array}{l}\text { Kesesuaian media pembelajaran dengan tingkat kemampuan peserta } \\
\text { didik }\end{array}$ & 4 \\
\hline 7 & Media terlihat jelas kegunaanya dalam tujuan pembelajaran & 4 \\
\hline 8 & $\begin{array}{l}\text { Media terlihat menarik dan sangat mendukung dalam penyajian } \\
\text { pembelajaran. }\end{array}$ & 4 \\
\hline 9 & Melatih kemampuan fisik motorik anak usia dini & 4 \\
\hline \multicolumn{2}{|c|}{ Rata-rata skor } & $\begin{array}{c}\text { Sangat } \\
\text { layak }\end{array}$ \\
\hline \multicolumn{2}{|c|}{ Keterangan } & \\
\hline
\end{tabular}

Berdasarkan uji coba terbatas RA Ummahat DDI Ujuna (Ibu Ratnawati S. Pd) di atas skor tiap aspek penilaian mendapatkan nilai 4 skor maksimal tiap aspek penilaian di kali $100 \%$, dibagi jumlah skor tiap aspek penilaian sehingga memperoleh nilai persentase dengan kategori sangat layak.

2. RA DWP 1 Kanwil Depertemen Agama ( Ibu Samsia, S. Pd. I )

\section{Hasil penilaian pendidik RA 1 DWP Kanwil Depag Prov. Sulteng}

\begin{tabular}{|c|c|c|}
\hline No & Butir pertanyaan & Skor \\
\hline 1 & $\begin{array}{l}\text { kesesuian media permainan sapi perah dengan tingkat perkembangan } \\
\text { anak usia dini }\end{array}$ & 4 \\
\hline 2 & $\begin{array}{l}\text { Kesesuaian media permainan sapi perah dengan tujuan pembelajaran } \\
\text { kecerdasan jamak anak usia dini }\end{array}$ & 4 \\
\hline 3 & Kesesuaian media dengan kebutuhan mengajar & 4 \\
\hline 4 & Kejelasan petunjuk permainan Sapi perah & 4 \\
\hline 5 & Bahan permaianan sapi perah tidak bahaya dan aman bagi anak-anak & 4 \\
\hline 6 & $\begin{array}{l}\text { Kesesuaian media pembelajaran dengan tingkat kemampuan peserta } \\
\text { didik }\end{array}$ & 4 \\
\hline 7 & Media terlihat jelas kegunaanya dalam tujuan pembelajaran & 4 \\
\hline 8 & $\begin{array}{l}\text { Media terlihat menarik dan sangat mendukung dalam penyajian } \\
\text { pembelajaran. }\end{array}$ & 4 \\
\hline 9 & Melatih kemampuan fisik motorik anak usia dini & 4 \\
\hline \multicolumn{2}{|r|}{ Rata-rata skor } & 4 \\
\hline & Keterangan & $\begin{array}{c}\text { Sangat } \\
\text { layak }\end{array}$ \\
\hline
\end{tabular}

Berdasarkan uji coba terbatas RA DWP 1 Kanwil Depertemen Agama (Ibu Samsia, S. Pd. I) di atas skor tiap aspek penilaian mendapatkan nilai 4 skor maksimal 
tiap aspek penilaian di kali 100\%, dibagi jumlah skor tiap aspek penilaian sehingga memperoleh nilai persentase dengan kategori sangat layak.

3. RA 2 DWP Kanwil Depertemen Agama (Ibu Ria Ika Rahayuningtyas)

Hasil penilaian pendidik RA 2 DWP Kanwil Depag Prov. Sulteng

\begin{tabular}{|c|l|c|}
\hline No & \multicolumn{1}{|c|}{ Butir pertanyaan } & Skor \\
\hline 1 & $\begin{array}{l}\text { kesesuian media permainan sapi perah dengan tingkat perkembangan } \\
\text { anak usia dini }\end{array}$ & 4 \\
\hline 2 & $\begin{array}{l}\text { Kesesuaian media permainan sapi perah dengan tujuan pembelajaran } \\
\text { kecerdasan jamak anak usia dini }\end{array}$ & 4 \\
\hline 3 & Kesesuaian media dengan kebutuhan mengajar & 4 \\
\hline 4 & Kejelasan petunjuk permainan Sapi perah & 3 \\
\hline 5 & Bahan permaianan sapi perah tidak bahaya dan aman bagi anak-anak & 3 \\
\hline 6 & $\begin{array}{l}\text { Kesesuaian media pembelajaran dengan tingkat kemampuan peserta } \\
\text { didik }\end{array}$ & 4 \\
\hline 7 & $\begin{array}{l}\text { Media terlihat jelas kegunaanya dalam tujuan pembelajaran } \\
\text { pembelajaran. menarik dan sangat mendukung dalam penyajian }\end{array}$ & 4 \\
\hline 9 & $\begin{array}{l}\text { Media terlihat menarik kemampuan fisik motorik anak usia dini } \\
\text { Rata-rata skor }\end{array}$ & Sangat \\
\hline \multicolumn{2}{|c|}{ Keterangan } \\
\hline
\end{tabular}

Berdasarkan uji coba terbatas RA DWP 2 Kanwil Depertemen Agama (Ibu Ria Ika Rahayuningtyas) di atas skor tiap aspek penilaian mendapatkan nilai terndah pada nomor 4 dan 5 seluruh skor tiap aspek penilaian di kali $100 \%$, dibagi jumlah skor tiap aspek penilaian sehingga memperoleh nilai persentase dengan kategori sangat layak.

Berdasarkan hasil pengujian terbatas dalam uji coba penelitian ini mendapatkan persentase dengan kategori sangat layak oleh RA Ummahat DDI Ujuna (Ibu Ratnawati S. Pd), dengan memberikan catatan bahwa penjelasan media pembelajaran harus secara keseluruhan contohnya harus di sampaikan kepada peserta didik bentuk asli dan bentuk media tiruan sapi secara umum pendapat dari ibu Ratnawati S. Pd. Masalah tehnik mengajar atau penyampaian kepada peserta didik, dan penilaian oleh RA DWP 1 Kanwil Depertemen Agama, (Ibu Samsia, S. Pd. I) memberikan masukan bahwa saat mengajarakan kepada anak-anak harus membawa dan memperkenalkan satu contoh produk susu agar anak tau susu yang dikonsumsi 
salah satunya berasal dari susu sapi dan RA DWP 2 Kanwil Depertemen Agama, (Ibu Ria Ika Rahayuningtyas) memberikan masukan mengenai tehnik mengajar mengenai vocal suara yang harus lebih keras agar anak-anak lebih fokus ke guru yang menjelaskan.

\section{Uji Coba lapangan}

Uji coba lapangan dilakukan oleh peserta didik di tiga sekolah yang masingmasing kualitas dan kuantitas nya berbeda-beda yaitu Raudhatul Athfal Ummahat DDI Ujuna Palu, RA DWP 1 Kanwil Depertemen Agama, dan RA DWP 2 Kanwil Depertemen Agama Yang memiliki alat permainan edukatif berbeda-beda, pada tahap ini peneliti membatasi jumlah anak di sesuaikan dengan keadaan lingkungan yang saat ini kurang baik yakni adanya wabah penyakit virus covid 19 sehingga hanya melibatkan 15 orang peserta didik, kemudian peserta didik diminta untuk mencoba produk dan memberikan penilaian terhadap produk yang dikembangkan melalui respon peserta didik, setelah mereka melakukan uji coba pemakaian produk, hasil uji coba ini dapat di lihat pada tabel berikut:

\section{Hasil Responden Uji Coba Lapangan}

\begin{tabular}{|c|c|c|c|}
\hline \multirow{2}{*}{$\begin{array}{l}\text { Indikator } \\
\text { Penilaian }\end{array}$} & \multirow[t]{2}{*}{ Materi } & \multicolumn{2}{|c|}{ Jumlah Respon } \\
\hline & & $\mathrm{Ya}$ & Tidak \\
\hline \multirow[t]{4}{*}{ Tampilan } & $\begin{array}{l}\text { Apakah adik-adik suka dengan warna media sapi perah } \\
\text { ini? }\end{array}$ & $\begin{array}{c}15 \\
\text { orang }\end{array}$ & - \\
\hline & $\begin{array}{l}\text { Apakah adik-adik suka dengan bentuk media sapi perah } \\
\text { ini? }\end{array}$ & $\begin{array}{c}14 \\
\text { orang }\end{array}$ & $\begin{array}{c}1 \\
\text { orang }\end{array}$ \\
\hline & Apakah bentuk media sapi perah ini jelas? & $\begin{array}{c}15 \\
\text { orang }\end{array}$ & - \\
\hline & Apakah adik-adik tertarik dengan permainan sapi perah? & $\begin{array}{c}13 \\
\text { orang }\end{array}$ & $\begin{array}{c}2 \\
\text { orang }\end{array}$ \\
\hline \multirow[t]{3}{*}{ Penyajian } & $\begin{array}{l}\text { Saya bersemangat memerah susu sapid an belajar } \\
\text { tentang hewan sapi }\end{array}$ & $\begin{array}{c}15 \\
\text { orang }\end{array}$ & - \\
\hline & $\begin{array}{l}\text { Permainan sapi perah membantu saya dalam belajar } \\
\text { tentang susu }\end{array}$ & $\begin{array}{c}14 \\
\text { orang }\end{array}$ & $\begin{array}{c}1 \\
\text { orang }\end{array}$ \\
\hline & $\begin{array}{l}\text { Saya ingin memberitahukan keberadaan permainan sapi } \\
\text { per ah kepada teman-teman saya }\end{array}$ & $\begin{array}{c}15 \\
\text { orang }\end{array}$ & $\begin{array}{c}1 \\
\text { orang }\end{array}$ \\
\hline
\end{tabular}

Dari tabel diatas dapat di lihat bahwa dua aspek yang di nilai dari peserta didik yaitu penyajian dan tampilan dengan banyaknya memberikan respon "YA" maka penulis menyimpulkan alat permainan edukatif sapi perah sangat layak di gunakan dalam proses pembelajaran anak usia dini. 


\section{Produk Akhir}

Setelah dilakukan penilaian produk alat permainan edukatif sapi perah, maka didapat saran, kemudian saran yang diberikan dijadikan masukan untuk merevisi produk adapun hasil revisi, Konstruk media pada aspek estetika/keindahan masih perlu di poles agar sesuai dengan aslinya maka di lakukanlah penambahan Koran sehingga propersi badan dan tingginya disesuaikan serta perubahan warna sapi perah dari warna coklat-putih ke warna hitam-putih. Hasil revisi pada gambar dibawah ini

Penambahan Koran pada wajah sapi agar tidak datar, serta perubahan pada tanduk dan telinga. Selanjutnya penambahan pada postur badan agar lebih panjang dan berisi.

\section{PEMBAHASAN}

Penelitian pengembangan alat permainan edukatif yang dihasilkan dalam penelitian ini adalah produk alat permainan edukatif sapi perah untuk mengembangkan beberapa aspek perkembangan anak usia dini di RA Ummahat DDI Ujuna, RA DWP 1 Kanwil Depertemen Agama dan RA DWP 2 Kanwil Depertemen Agama, alasan penulis melakukan penelitian dilokasi tersebut karena ada beberapa kendala dalam menunjang pembelajaran anak usia dini secara optimal, kendalakendala yang dialami beraneka ragam, mulai dari faktor internal atau faktor dari dalam diantaranya adalah anak masih pasif pada saat pembelajaran di kelas, hal tersebut karena masih minimnya alat permainan edukatif yang ada di sekolah tersebut, faktor eksternal atau faktor dari luar yaitu masih kurangnya fasilitas belajar seperti permainan-permainan yang baru dan unik sehingga anak lebih bersemangat lagi.

Berdasarkan beberapa kendala yang dijelaskan diatas, penulis mencoba melakukan solusi untuk mengatasi masalah tersebut dengan melakukan penelitian pengembangan. Penelitian pengembangan dilakukan oleh penulis dengan mengembangkan produk sebagai media bermain sambil belajar untuk anak. Produk yang dikembangkan adalah alat permainan edukatif sapi perah dalam pembelajaran anak usia dini.

Uji kelayakan produk dalam penelitian ini melalui beberapa tahapan guna mendapatkan penilaian, saran dan komentar sehingga alat permainan edukatif sapi perah yang dikembangkan layak untuk digunakan dalam pembelajaran anak usia dini, uji kelayakan produk tersebut terbagi kedalam beberapa tahapan, yaitu : 1) tahap uji validasi, 2) tahap uji coba terbatas, 3) tahap uji coba lapangan. 
Pada tahap validasi tim validator melakukan penilaian dan memberikan saran, pada tahap tersebut data hasil penilaian mendapatkan persentase dengan kategori valid oleh validator I dengan memberikan nilai sebesar 87, penilaianValidator II memberikan nilai 87 dengan kategori valid, valoidator III Kategori valid dengan memberikan nilai 86, dan validator IV kategori valid dengan memberikan nilai 80 . Sehingga alat permainan edukatif sapi perah yang dikembangkan sudah layak untuk digunakan dan perlu dilakukan revisi sesuai saran dari tim validator.

Adapun perbaikan atau revisi yang dilakukan terhadap produk adalah sebagai berikut:

1.Konstruk media pada aspek estetika/keindahan masih perlu dipoles agar sesuai dengan aslinya

2.Proporsi badan dan tingginya perlu di sesuaikan

3.Wajah sapi masih datar, dan masih menyerupai hewan anjing maka perlu di tambah agar kelihatan lebih berisi

4.Pemilihan warna sebaiknya warna hitam putih

Pada saat melakukan perbaikan yang telah disarankan oleh tim validator mengacu pada ciri-ciri alat permainan edukatif yang baik, desain yang mudah dan sederhana yang tentunya dapat dipahami anak-anak ketika melihatnya, maka dari itu penulis berusaha memperbaiki alat permainan edukatif sapi perah sesuai dengan saran-saran dari tim ahli validator.

Sedangkan pada tahap II, penilaian uji terbatas, dalam uji coba ini melibatkan guru di RA Ummahat DDI Ujuna, RA DWP I Kanwil Depertemen Agama, dan RA DWP II Kanwil Depertemen Agama untuk menilai produk yang dikembangkan penilaian coba terbatas di RA Ummahat DDI Ujuna oleh Ibu Ratnawati S.Pd memberikan nilai 4 dengan kategori sangat layak, RA DWP 1 Kanwil Depertemen Agama oleh Ibu Samsia S.Pd.I memberikan nilai 4 dengan kategori sangat layak, RA DWP 2 Kanwil Depertemen Agama oleh Ibu Ria Ika Rahayuningtyas memberikan nilai 3,7 dengan kategori sangat layak. Dalam uji coba terbatas para guru juga memberikan pendapatnya terkait tentang media alat permainan sapi perah sebagai berikut:

1. RA Ummahat DDI Ujuna Palu

Kota Palu, sulawesi Tengah, belum memiliki kebun binatang yang lengkap, hewan sapi merupakan hewan yang mudah dijumpai sebagai binatang ternak akan tetapi belum adanya tempat atau pabrik pengeloaan susu dan juga sebagai tempat kunjungan atau belajar tentang produksi susu, kebutuhan biaya, pengetahuan dan lingkungan untuk mengembangkan sebuah usaha peternakan sapi perah sendiri tidaklah murah sehingga sulit adanya akses bagi 
pelajar untuk mempelajarinya secara langsung, sebagaimana pendapat dari salah satu guru di RA Ummahat DDI Ujuna Palu "media ini sangat bagus karena di kota palu sendiri belum mempunyai kebun binatang yang lengkap, hewan sapi hanya ada yang local, sedangkan untuk produksi susu belum ada tempat yang menjadi produksi dan untuk mengajarkankan anak usia dini cara memerah sapi dan memperkenalkan kepada anak secara real sumber susu salah satunya dari binatang sapi.",10

\section{RA DWP 2 Kanwil Depertemen Agama Sulteng}

Dalam pembelajaran anak usia dini khususnya tema binatang dengan hewan sapi belum adanya media alat permainan edukatif yang digunakan secara langsung untuk mengajarkan anak usia dini sebagaimana pendapat dari salah satu guru RA DWP 2 Kanwil Depertement Agama Sulteng "Sebelumnya saya belum pernah melihat atau menjumpai media seperti ini, medianya bagus sesuai dengan tingkat pembelajaran anak usia dini dengan tema binatang, selama ini anak-anak minum susu dan tahu asal muasal susu hanya sebatas sumber, proses nya belum, selama ini anak-anak hanya dikenalkan melalui gambar atau video, tapi secara langsung/praktek belum." $" 11$

\section{RA DWP 1 Kanwil Depertemen Agama Sulteng}

Desain media alat permainan edukatif sapi perah dari bahan yang tidak membahayakan dan tentunya digunakan sebagai media pembelajaran yang dapat merangsang aspek perkembangan anak sebagaimana pendapat dari salah satu guru di RA DWP 1 Kanwil Depertemen Agama Sulteng "Medianya bagus, melatih motorik anak usia dini, dan meraka jadi tahu cara memerah susu, medianya tidak berbahaya dan tidak mencelakai anak-anak, selama ini memperkenalkan anak-anak melaui poster, dan ini menarik karena anak-anak dapat berperan langsung dari media buatan yang menyerupai asli, sehingga mereka bisa menyentuh secara langsung dan belajar cara memerah susu." ${ }^{\prime 2}$

Dari ketiga pendapat guru tersebut di tiga sekolah peneliti dapat menyimpulkan bahwa alat permainan edukatif sapi perah ini, merupakan APE baru dalam proses pembelajaran anak usia dini yang nantinya dapat digunakan dalam

\footnotetext{
${ }^{10}$ Ratnawati, Selaku Guru Kelas RA Ummahat DDI Ujuna Palu, "Hasil Wawancara”, Kota Palu, Kecamatan Palu Barat, Pada Tanggal 12 Maret 2021

${ }^{11}$ Ika Rahayuningtyas Ria, Selaku Guru di RA DWP 2 Kanwil Depag Prov. Sulteng, "Hasil Wawancara", Kota Palu, Kecamatan Palu Barat, Pada Tanggal 17 Maret 2021

12 Samsia, Selaku Guru di RA DWP Kanwil Depag Prov. Sulteng, "Hasil Wawancara”, Kota Palu, Kecamatan Palu Barat, Pada Tanggal 22 Maret 2021
} 
proses pembelajaran, harapanya dapat meningkat aspek perkembangan anak usia dini.

Uji coba lapangan dilakukan di tiga sekolah yang masing-masing kualitas dan kuantitas nya berbeda-beda yaitu Raudhatul Athfal Ummahat DDI Ujuna Palu, Raudhatul Athfal 1 Dharma Wanita Persatuan Kanwil Depertemen Agama, dan Raudhatul Athfal 2 Dharma Wanita Persatuan Kanwil Depertemen Agama. Yang memiliki alat permainan edukatif berbeda-beda, pada tahap ini peneliti membatasi jumlah anak di sesuaikan dengan keadaan lingkungan yang saat ini kurang baik yakni adanya wabah penyakit virus covid 19 sehingga hanya melibatkan 15 orang peserta didik, kemudian peserta didik diminta untuk mencoba produk dan memberikan penilaian terhadap produk yang dikembangkan melalui respon peserta didik dengan melakukan wawancara terkait tampilan, penyajian dalam penggunaan alat permainan eduktatif sapi perah adapun respon di RA Ummahat DDI Ujuna Palu anak-anak banyak bertanya apakah alat tersebut bisa dinaiki dan di mainkan, mereka juga tertarik dengan cara memerah susu, yang selama ini mereka mempelajarinya lewat media video atau gambar, di RA DWP 1 Kanwil Depertemen Agama Sulteng sekolah ini terkesan hampir lengkap alat permainanya namun alat permainan edukatif sapi perah belum pernah digunakan dalam pembelajaran, penulis mengambil alih proses pembelajaran dengan tema binatang ciptaan Allah sub tema sapi perah, disekolah ini anak-anak sangat antusias saat dikenalkannya alat permainan sapi perah, semua anak mendekati alat permainan tersebut dan semua ingin mencobanya dan di RA DWP 2 Kanwil Depertemen Agama Sulteng, sekolah ini terkesan sangat kekurangan alat permainan sehingga ketika dikenalkanya alat permainan baru yang sebelumnya belum perna mereka gunakan sehingga anak-anak disekolah ini tertarik dan memperhatikan cara penggunaan alat permainan tersebut saat penulis menjelaskan.

Pada uji coba lapangan mendapatkan respon baik peserta didik dari segi tampilan dan penyajian penulis dapat menyimpulkan bahwa penggunaan alat permainan edukatif sapi perah dalam pembelajaran membuat anak lebih antusias, merasa senang dan bersemangat ketika proses belajar mengajar, media alat permainan edukatif sapi perah ini juga sangat berpengaruh terhadap aspek perkembangan anak usia dini, diantaranya aspek kognitif anak jadi paham tentang proses pemerahan susu, manfaat susu dan salah satu sumber susu, aspek motorik yang di kembangkan dalam media ini adalah anak dapat berintraksi langsung pada media sehingga motorik halus anak bekerja, aspek seni anak dapat mengetahui warna pada media dan suara hewan sapi, dan adanya intraksi dalam belajar mengajar kepada peserta didik sehingga dapat mengembangkan aspek bahasa anak usia dini, 
aspek agama yakni dengan tema hewan ciptaan Allah dan salah satu kegunaanya sebagai hewan qurban. sehingga produk alat permainan edukatif sapi perah siap atau layak digunakan dalam pembelajaran anak usia dini.

Berdasarkan nilai rata-rata hasil penilaian produk melalui uji coba validasi, uji coba terbatas dan uji coba lapangan, hasil pengembangan ini dikatakan layak untuk digunakan dalam pembelajaran anak usia dini.

\section{KESIMPULAN}

Penelitian dan pengembangan ini telah menghasilkan produk alat permainan edukatif (APE) sapi perah dalam pembelajaran anak usia dini, secara keseluruhan produk alat permainan edukatif sapi perah dikategorikan layak dalam pembelajaran anak usia dini di RA Ummahat DDI Ujuna Palu, RA DWP 1 Kanwil Depertemen Agama Sulteng, RA DWP 2 Kanwil Depertemen Agama Sulteng.

Hasil penelitian menunjukkan, (1) Dihasilkan alat permainan edukatif sapi perah yang layak digunakan dalam pembelajaran anak usia dini. (2) Alat permainan edukatif sapi perah terdiri dari kawat ram/parabola sebagai penguat bagian dalam dilapisi sagu dan lem, di perindah dengan cet, lalu ditamhkan botol madu tj dan handsoon sebagai alat pemerah susu, dan anak dapat menggunkan media tersebut dengan aman. (3) hasil uji coba validasi oleh tim validator mendapatkan kategori valid, hasil uji coba terbatas oleh guru mendapatkan kategori layak dan hasil iji coba lapangan oleh peserta didik mendapatkan respon baik, sebagaimana telah dijelaskan pada uraian seblumnya.

\section{SARAN}

Berdasarkan hasil penelitian pengembangan telah menghasilkan alat permainan edukatif sapi perah dalam pembelajaran anak usia dini, maka ada beberapa saran sebagai berikut:

1. Bagi penulis dapat mengembangkan media pembelajaran berupa alat permainan edukatif dengan tema lainya sehingga dapat meningkatkan evektivitas pembelajaran.

2. Bagi pembaca dapat melakukan pengembangan lebih lanjut terhadap media pembelajaran terutama alat permainan edukatif sapi perah agar dapat dihasilkan produk yang inovatif untuk digunakan dalam pembelajaran.

3. Bagi guru dapat menerapkan alat permainan edukatif sapi perah dalam pembelajaran sehingga perkembangan anak berkembang secara optimal. 


\section{DAFTAR PUSTAKA}

Mansyur, Pendidikan Anak Usia Dini Dalam Islam, Yogyakarta:Pustaka Pelajar, 2011

Mukhtar latif, dkk, Orientasi Baru Pendidikan Anak Usia Dini : Teori dan Aplikasinya cet.3; Jakarta : Prenadamedia group. 2016

Margono, metodelogi penelitian pendidikan (Jakarta: Rineka cipta, 2010

Punaji Setyosari, Metode Penelitian Pendidikan Dan Pengembangan, Jakarta: Prenadamedia Group, 2013

Peraturan Menteri Pendidikan Nasional Republik Indonesia No 137 Tahun 2014 Tentang Standar Pendidikan Anak Usia Dini, Jakarta: Madya Duta Jakarta

Romlah, Untung Nopriansyah, Sigit Purnama, Korelasi Kepemimpinan Kepala Taman Kanak-Kanak Terhadap Kinerja Kompetensi Pedagogik Dan Kompetensi Profesional Guru , Al Athfaal:Jurnal ilmiah Pendidikan Anak Uisa Dini . Vol. 2 No. 12019

Sugiyono, Metode Penelitian Pendidikan Pendekatan Kuantitatif, Kualitatif Dan RnD Bandung : Alfabeta, 2015

Yasa, "Pengembangan Bahan Ajar Online Mata Kuliah Microteaching Dengan Model Borg \& Gall Pada Program S1 Pendidikan Bahasa Inggris STKIP Agama Hindu Singaraja.” Teknologi Pendidikan, 2012

Yuliani Nurani Sujiono, Konsep Dasar Pendidikan Anak Usia Dini, Jakarta: PT Indeks, 2005

Zaman, badru, Dkk, Media dan Sumber Belajar TK., Tanggerang: Universitas Terbuka, 2013 